Agro-Science Journal of Tropical Agriculture, Food, Environment and Extension Volume 20 Number 4 (Special Issue, October 2021) pp. 59 - 64

ISSN 1119-7455

\title{
THE ROLE OF SOIL IN SAVING HUMAN RACE FROM COVID-19 PANDEMIC
}

\author{
Asadu C.L.A. \\ Department of Soil Science, University of Nigeria, Nsukka \\ Corresponding email: charles.asadu@unn.edu.ng
}

\begin{abstract}
Soil is the most complex part of land as its contents are made of all the other key components of land namely geology (soil minerals), hydrology (soil water), atmosphere (soil air), and organisms including man (soil organic matter including dead bodies). This is why the functions of the soil are not only numerous but also indispensable. Among the functions, the role of the soil in sustaining human life remains unimaginable. Over 3.8 million people have been killed by COVID-19 by June 15, 2021 in the world and more are still dying. Some unrecorded millions died of hunger as a result of the lockdown during the peak of COVID-19 pandemic. Where are these dead bodies and materials associated with those that died of COVID-19? Where did all the food palliatives (rice, maize, wheat, yam, gari, vegetable oil, etc.) come from? The human body is composed of approximately $64 \%$ water, $20 \%$ protein, $10 \%$ fat, $1 \%$ carbohydrate, $5 \%$ minerals. When decomposed these various components result to various gaseous compounds and residues that are harmful to human life and environment. When dead bodies are buried human health and environment are saved. The dead bodies, the wastes and their contents are in the soil providing "palliatives" to soil microorganisms while protecting the remaining human population and the environment. Cremation products also end up in the soil. The soil also provided and still provides the food palliatives. Thus, the soil is our number one saviour against COVID-19 pandemic and can be adjudged as the saviour of the human race to date. Coincidentally man was made from the soil and must return to the soil.
\end{abstract}

Key words: soil functions, burial, cremation, palliatives, COVID-19

\section{INTRODUCTION}

Soil is not a simple entity but a complex mixture of minerals, water, air, organic matter (the decaying remains of once-living things inclusive), and countless organisms very many of which are microscopic. It is part of land defined as the area of the earth's surface the characteristics of which embrace all reasonably stable, or predictable cyclic attributes of the atmosphere vertically above and below this area including those of the atmosphere, the soil and underlying geology, the hydrology, the plant and animal populations, and the results of past and present human activity, to the extent that these attributes exert a significant influence on the present and future uses of the land by man (FAO, 1976). The first function of the soil was in the making of man. This is how man was made. "Then the Lord God took some soil from the ground and formed a man out of it; he breathed life-giving breath into his nostrils and the man began to live" (Genesis 2: verse 7). The story of soil is essentially the story of humanity because the Latin word for 'man', homo, is derived from the same root as 'humus' linking the association between human beings and soil (Hillel, 1991).

Soil is the "skin of the earth." capable of supporting plant life and is vital to life on earth. There are more organisms in a handful of soil (tablespoon), in moist climates than there are people on the planet. These organisms primarily decompose plant and animal residues, but are responsible for many other processes, as well, especially in making nutrients available for plants to use. Soil is the unconsolidated mineral or organic matter on the surface of the earth that has been subjected to and shows effects of genetic and environmental factors of: climate (including water and temperature effects), and macro- and microorganisms, conditioned by relief, acting on parent material over a period of time (SSSA, 2021). Unfortunately, not a reasonable fraction of human population understands what soil means.

It has been reported that the trouble with soils is that we all just treat them like dirt but soil is fundamental to our life on earth (Allton, 2013). The soil remains the base for sustaining agricultural production that can feed the ever-growing population of the world irrespective of the use of soilless media like hydroponics to raise crops. This role is as old as mankind and one of the major functions recognized by early soil scientists because, before the development of pedology in the 19th century, agricultural soil science (or edaphology) was the only branch of soil science. Early soil scientists viewed soils only in terms of their agricultural potentials (production of food and fiber). 
With science and development more roles of soils have been established; soil is habitat for soil organisms, making up more than half of all "life" on the planet, a biochemical or nutrient reactor which absorbs, releases (i.e., desorbs), and transforms inorganic and biochemical compounds such as essential plant nutrients, pesticides, minerals, heavy metals, and numerous other compounds, a hydrologic buffer which stores (i.e., water holding capacity) and regulates the flow (i.e., drainage) of water in the landscape, and a foundation for the physical support of structures including everything from plants to skyscrapers (Asadu, 2012).

The corona virus disease (COVID-19) is caused by a virus discovered only when it had started ravaging human life. Viruses appear to be the only microorganism or particulate with the highest negative interpretation because they are often associated with disease both in plant and animals. The diseases caused by viruses are more lethal than those caused by other microorganisms. It has been reported that if a survey were to ask non-virologists for their opinions about viruses, the word "good" would be unlikely to arise, instead, words such as "disease," "infection," "suffering," or "life-threatening" would likely dominate, as people primarily think of viruses such as HIV, Ebola virus, Zika virus, influenza virus, or whatever new outbreak is in the news (Mietzsch and Agbandje-McKenna, 2017).

COVID-19 started as an epidemic in China in Wuhan, Hubei province and the first report was dated February 26th, 2020 (Zhu et al., 2020) but the World Health Organization (WHO) declared it as pandemic on March 11th, 2020 mainly due to the speed and scale of the transmission of the disease (WHO, 2020). Globally, as of 15 June 2021 , there have been $175,987,176$ confirmed cases of COVID-19, including 3,811,561 deaths, and a total of 2,310,082,345 vaccine doses have been administered (WHO, 2021). Except for few cases of cremation especially by the Indians; all the dead bodies were buried in the soil. This paper examines how the soil has contributed to saving the world from annihilation by COVID-19 pandemic.

\section{Soil as Sources of Food and Clothing Palliatives}

The main benefit obtained from the soil is that it is the medium for the growth of all kinds of plants and animals. During the COVID-19 lockdown, the entire world stood still, no production of any kind. The world depended on food stored in various forms which were doled out as palliatives. There are over 10,000 edible species of plants. These plants acquire their minerals (nutrients) and water from the soil. Animals acquire their nutrients from plants grown on soils directly from gazing fields for herbivores or from feeds manufactured from plant products especially cereals such as maize, wheat, rice' as well as wastes from root and tuber crops. These provide humans with the minerals, vitamins, and proteins that they need to live.
All clothing materials come from plants and animals that depend on soil. Leather, wool, and furs come from animals that humans have raised or hunted. Linen and cotton are woven together from plant fibers, and silk is created using the silkworm (animal) on a silk plant. Clothes that are made from polyester and other types of man- made chemicals still come from natural products, like coal which came from historic organic matter that grew on soils.

Soil is a reservoir of nutrients and living organisms. These living soil organisms are responsible for complicated transformations both organic and inorganic materials found on and inside the soil that are required to produce both plants and animals consumed as foods by humans and feeds by animals. This complicated transformation is responsible for sanitizing our environment leading to the healthy foods people ate not only during the COVID-19 lockdown but since the lifting of the lockdown.

\section{Soil Takes Care of Dead Bodies}

This is one of the major roles of soil in saving humanity from COVID-19 pandemic. Over 3 million deaths have been reported in the world associated with the pandemic (WHO, 2021). Most of these dead bodies were buried in the soil and one could imagine the health implications if the soil was not there to take them. In addition, there were clinical materials associated with the dead also buried or burnt with the residua and gasses produced eventually ending up in soil. The soil does all these because of numerous microorganisms in the soil and this is one the reasons soil scientists believe that "soil is life and it is alive" and this was the theme of World Soil Day (SSSN, 2013). Soils provide habitat for animals that live in the soil (such as groundhogs and mice) to organisms (such as bacteria and fungi), that account for most of the living things on earth.

Wikipedia (2021) gave a vivid account of burial, also known as interment or inhumation, as a method of final disposition whereby a dead body is placed into the ground, sometimes with objects. This is usually accomplished by excavating a pit or trench, placing the deceased and objects in it, and covering it over. A funeral is a ceremony that accompanies the final disposition. Humans have been burying their dead since shortly after the origin of the species. Burial is often seen as indicating respect for the dead. It has been used to prevent the odor of decay, to give family members closure and prevent them from witnessing the decomposition of their loved ones, and in many cultures it has been seen as a necessary step for the deceased to enter the afterlife or to give back to the cycle of life.

Our forefathers were great soil scientist as well as environmentalists because they knew soil depth six feet $(1.8 \mathrm{~m})$ dead bodies should be buried under normal situations as it would take donkey years for 
the body to revert to soil if buried deeper (Asadu, 2012). This is simply because this depth is about the limit for active microbial activities responsible for converting such bodies to soil materials in a normal soil. In fact, soil scientists limit most of their studies to $1.8 \mathrm{~m}$ depth. There is an adage in Igbo culture that what you need from the world after death is the six feet grave (Asadu, 2012).

Methods of burial may be heavily ritualized and can include natural burial (also called "green burial"); embalming or mummification; and the use of containers for the dead, such as shrouds, coffins, grave liners, and burial vaults, all of which can retard decomposition of the body. Sometimes objects or grave goods are buried with the body, which may be dressed in fancy or ceremonial garb. Depending on the culture, the way the body is positioned may have great significance (Wikipedia, 2021).

The location of the burial may be determined by taking into account concerns surrounding health and sanitation, religious concerns, and cultural practices. Some cultures keep the dead close to provide guidance to the living, while others "banish" them by locating burial grounds at a distance from inhabited areas. Some religions consecrate special ground to bury the dead, and some families build private family cemeteries. Most modern cultures document the location of graves with headstones, which may be inscribed with information and tributes to the deceased. However, some people are buried in anonymous or secret graves for various reasons. Sometimes multiple bodies are buried in a single grave by choice (as in the case of married couples), due to space concerns, or as mass graves as a way to deal with many bodies at once. This was the case during the COVID-19 pandemic in many countries.

Alternatives to burial include cremation (and subsequent interment), burial at sea and cryopreservation. Some human cultures may bury the remains of beloved animals. Humans are not the only species to bury their dead; the practice has been observed in chimpanzees, elephants, and possibly dogs (Wikipedia, 2021). It has been reported that there is no culture on earth that leaves a body without any ritual. It is one of the few universals. We have a very strong notion of the integrity of the body, and a great preoccupation with what happens to it, even though we know the person inside is gone (Stromberg, 2015).

The vast majority of humans who have ever lived share the same fate after death - decomposition. Unless your body is frozen, cremated, or otherwise destroyed after you die, it will inevitably be consumed by bacteria, insects, and animals that recycle your organic substances into new forms of life. Even today, the protection of embalming fluid and wooden caskets does not stop the process - it only delays it slightly. Given how universal decomposition is, it is a bit surprising that until quite recently, our knowledge of it was fairly thin (Stromberg, 2015).
Within a few days, this frenzy of feeding leads to the second stage: bloat. Living organisms present in soil that can be involved in decomposition and transformation various dead matter including dead bodies include bacteria, fungi, archaea, actinomycetes, algae, protozoa, and a wide variety of larger soil fauna including springtails, mites, nematodes, earthworms, ants, and some arthropods with exoskeletons like mites, millipedes, centipedes, springtails and grubs that spend all or part of their life underground, even larger organisms such as burrowing rodents.

As bacteria breakdown the solid components of the body, they release gases - hydrogen sulfide, carbon dioxide, and methane - which cause the body to swell enormously (Stromberg, 2015). These gasses are dangerous to human life directly or as greenhouses gasses contribute to atmospheric warming and climate change. Most of these bacteria are aerobic, meaning that they require oxygen from the soil environment. However, other bacteria need to live without oxygen, and other types can live both with, and without oxygen. These aerobic and anaerobic conditions in the soil or grave give both types of bacterial advantage in the decomposition process. The numerous dead bodies due to the COVID-19 would have boosted bacterial population worldwide and possibly increased atmospheric nitrogen fixation in the soil, another advantage of bacteria in increasing soil fertility and productivity.

Soil fungi are also large components of the soil that come in various sizes, shapes, and colors. Mushrooms have underground roots (mycelium) that absorbs nutrients and water until they are ready to flower in the mushroom form. They tolerate acidity, which makes them very important to decompose materials in very acidic forests that microbes cannot do, they can also decompose lignin or any woody material buried with the dead body. Another advantage of fungi is symbiotic relationship with plant roots. These are called Mycorrhiza, and they help plants absorb more water and nutrients, increase drought resistance, and reduce infection by diseases.

The roles of each microorganism in the decomposition of organic materials are well known and are not reproduced here, but it should be stressed that how they work in tandem to impact the soil chemical and physical properties is complex. Their roles are important in making up the environment we call soil and in bringing about numerous transformations that are vitally important to life. The results of these complex interactions among soil organisms which we harvest as sustainable clean environment and continued human life on earth are often taken for granted by humans. Let us pay more attention to the soil and keep it alive so that we can live too. 


\section{Transformation of Decomposition Products}

The chemical process of decomposition is complex and involves the breakdown of soft tissue, as the body passes through the sequential stages of decomposition (Clark et al., 1997). Autolysis and putrefaction also play major roles in the disintegration of cells and tissues (Forbes, 2008) The human body is composed of approximately: $64 \%$ water, $20 \%$ protein, $10 \%$ fat, $1 \%$ carbohydrate and 5\% minerals (Janaway et al., 2009). The decomposition of soft tissue is characterized by the breakdown of these macromolecules, and thus a large proportion of the decomposition products should reflect the amount of protein and fat content initially present in the body (Dent et al., 2004). As such, the chemical process of decomposition involves the breakdown of proteins, carbohydrates, lipids, nucleic acids, and bone.

\section{Some Important Products of Body} Decomposition and their Faith in Soils

Soil and soil organisms do not function only to decompose dead organic matter but to transform the products into useful nutrients involved in natural processes like photosynthesis, and various cycles like carbon, nitrogen and sulfur cycles in nature. Soils also act as a living filter ensuring that the harmful products of organic matter decomposition do not enter into the natural aquifer. This is because soils have the inherent capacity to absorb, hold, release, alter, and purify the water in terrestrial systems so that living things can use them over and over again.

\section{Hydrogen Sulfide}

This one of the major gasses produced when dead bodies decompose. It is a colourless, highly flammable and explosive gas also produced naturally by other decaying organic matter and by certain industrial processes. It can also be released from sewage sludge, liquid manure, sulfur hot springs, and natural gas or as a by-product of many industrial processes including petroleum refining, tanning, mining, wood-pulp processing, rayon manufacturing, sugar-beet processing, and hotasphalt paving. Hydrogen sulfide $\left(\mathrm{H}_{2} \mathrm{~S}\right)$ has a characteristic rotten-egg odour; however, olfactory fatigue may occur and consequently it may not provide adequate warning of hazardous concentrations of the gas. Hydrogen sulfide is used to produce elemental sulfur, sulfuric acid, and heavy water for nuclear reactors.

As in the soil, plants can exchange sulfur from the plant to the atmosphere and vice versa in the form of $\mathrm{H}_{2} \mathrm{~S}, \mathrm{COS}$, and $\mathrm{CS}_{2}$, to incorporate the $\mathrm{S}$ in the assimilation pathways of plants. In recent years, both $\mathrm{H}_{2} \mathrm{~S}$ and several of the derivative compounds (polysulfides and polysulfanes) or donors of this molecule have aroused great interest for their participation as oxidative stress reducers, in cellular signaling, and as post-translational modifiers. Because of its lipophilic nature, $\mathrm{H}_{2} \mathrm{~S}$ is biologically reactive, since it can rapidly cross the membranes of cells without the intervention of channels. A possible $\mathrm{H}_{2} \mathrm{~S}$ signaling mechanism is the formation of persulfides or hydrosulfides (RSSH) from the protein cysteine residues. It is assumed that $\mathrm{H}_{2} \mathrm{~S}$ interacts in this way, with a great diversity of proteins such as channels, transcription factors, and enzymes (Predmore et al., 2012; Li and Lancaster, 2013).

The $\mathrm{H}_{2} \mathrm{~S}$ auto-oxidises in the presence of $\mathrm{O}_{2}$, forming polysulfanes, $\mathrm{SO}_{3}{ }^{2-}, \mathrm{S}_{2} \mathrm{O}_{3}{ }^{2-}$, and $\mathrm{SO}_{4}{ }^{2-}$ (Stimler et al., 2012); additionally, $\mathrm{H}_{2} \mathrm{~S}$ is a precursor of biological polysulfides (Kharma et al., 2019). Polysulfanes, polysulfides (with $\mathrm{Sn}>2$ ), and RSSH contain $\mathrm{S}^{0}$ atoms, which allows a diversity of oxidation states between the sulfur atoms and allows the molecules a dual character as oxidants and reducers. This diversity probably contributes to a multifunctionality character of the signaling of $\mathrm{H}_{2} \mathrm{~S}$ and its derived compounds. The $\mathrm{H}_{2} \mathrm{~S}$ donor compounds have been explored in the agricultural field for their possible applications in improving the productivity and quality of crops. It has been found that $\mathrm{H}_{2} \mathrm{~S}$ mediates in signaling an increase in crop tolerance to different stresses such as heavy metals $(\mathrm{Cd}, \mathrm{Cr}, \mathrm{Cu}, \mathrm{Al}, \mathrm{As})$, salinity, high temperature, and water deficit (Christou et al., 2013). Although $\mathrm{H}_{2} \mathrm{~S}$ has comparable reactivity with glutathione (GSH) against $\mathrm{H}_{2} \mathrm{O}_{2}$ and free radicals, it is believed that its value as a cellular antioxidant is limited because of its low concentration in vivo (Predmore et al., 2012; Li and Lancaster, 2013). The GSH is often referred to as the body's master antioxidant. Composed of three amino acids cysteine, glycine, and glutamate - GSH can be found in virtually every cell of the human body. The highest concentration of GSH is in the liver, making it a critical antioxidant in the body's detoxification process.

\section{Carbon Dioxide}

Carbon dioxide $\left(\mathrm{CO}_{2}\right)$ is a colourless and essentially odourless gas that is 1.5 times as dense as air. It is not toxic, although a large concentration could result in suffocation simply by causing a lack of oxygen in the body. From the fermentation of glucose (a sugar) one of the end products of fat, oil and carbohydrate decomposition-mineralization process in the body, carbon dioxide is produced:

$$
\mathrm{C}_{6} \mathrm{H}_{12} \mathrm{O}_{6} \rightarrow 2 \mathrm{C}_{2} \mathrm{H}_{5} \mathrm{OH}+2 \mathrm{CO}_{2} .
$$

Carbon dioxide is very useful in sustaining both plant and animal life on earth through a wellknown process called photosynthesis. In the process carbohydrate is produced and carbon dioxide is removed from the atmosphere and replaced by oxygen (Zundhld, 2021). 


\begin{abstract}
Methane
Methane oxidation is a microbial metabolic process for energy generation and carbon assimilation from methane that is carried out by specific groups of bacteria, the methanotrophs. Methane is oxidized by molecular oxygen to carbon dioxide (Bürgmann, 2011) useful in photosynthesis (Zundhld, 2021).
\end{abstract}

\section{Bone Decomposition}

Bones are largely a fibrous matrix of collagen fibers, impregnated with calcium phosphate. In warm, damp environments, bacteria and fungi will attack the collagen protein and the skeleton will crumble over the course of a few years. Bone is quite resistant to degradation but will eventually be broken down by physical breaking, decalcification, and dissolution. The rate, at which bone is degraded, however, is highly dependent on its surrounding environment. When soil is present, its destruction is influenced by both abiotic (water, temperature, soil type, and $\mathrm{pH}$ ) and biotic (fauna and flora) agents but calcium phosphate is not attacked by micro-organisms, but it reacts readily with acid, so bones decompose fastest in well aerated soils (Forbes, 2008).

\section{Cremation and Natural Burial}

Cremation is a method of final disposition of a dead body through burning also (Sublette et al., 1992). It has its own environmental health implications. It can serve as an alternative to burial. In some countries, including India and Nepal, cremation on an open-air pyre is an ancient tradition. Starting in the 19th century, cremation was introduced or reintroduced into other parts of the world. In modern times, cremation is commonly carried out with a closed furnace (cremator), at a crematorium (Sublette et al., 1992). However, Christian and Islamic religions are generally opposed to it essentially due to some belief on resurrection or life after death. This stems from the belief associated with Aquinas theology that humans are a composite of soul and body, that a soul all by itself would not be a human being (Pasnau, 2002).

Despite being an obvious source of carbon emissions, cremation also has environmental advantages over burial, depending on local practice. Studies by Elisabeth Keijzer for the Netherlands Organization for Applied Research found that cremation has less of an environmental impact than a traditional burial (the study did not address natural burials), while the newer method of alkaline hydrolysis (sometimes called green cremation or resomation) had less impact than both. The study was based on Dutch practice; American crematoria are more likely to emit mercury, but are less likely to burn hardwood coffins (Rennenberg and Herschbach, 2014).
Keijzer's studies also found that a cremation or burial accounts for only about a quarter of a funeral's environmental impact; the carbon emissions of people travelling to the funeral are far greater (Rennenberg and Herschbach, 2014).

Each cremation requires about $110 \mathrm{~L}$ (28 US gal) of fuel and releases about $240 \mathrm{~kg}$ $(540 \mathrm{lb})$ of carbon dioxide into the atmosphere. Thus, the roughly 1 million bodies that are cremated annually in the United States produce about $240,000 \mathrm{t}(270,000$ short tons $)$ of carbon dioxide, which is more $\mathrm{CO}_{2}$ pollution than 22,000 average American homes generate in a year (Kopriva et al., 2012). The environmental impact may be reduced by using cremators for longer periods, and relaxing the requirement for a cremation to take place on the same day that the coffin is received, which reduces the use of fossil fuel and hence carbon emissions. Cremation is therefore becoming more friendly toward the environment ( $\mathrm{Li}$ and Lancaster, 2013). Some funeral and crematorium owners offer a carbon neutral funeral service incorporating efficientburning coffins made from lightweight recycled composite board (Predmore et al., 2012).

Burial is a known source of certain environmental contaminants, with the major ones being formaldehyde used in preserving the dead body and the coffin itself. Cremation can also release contaminants, such as mercury from dental fillings (Rennenberg and Herschbach, 2014). In some countries such as the United Kingdom, the law now requires that cremators be fitted with abatement equipment (filters) that remove serious pollutants such as mercury.

Another environmental concern is that traditional burial takes up a great deal of land space. In a traditional burial, the body is buried in a casket made from a variety of materials. In the United States, the casket is often placed inside a concrete vault or liner before burial in the ground. While individually this may not take much room, combined with other burials, it can over time cause serious space concerns. Many cemeteries, particularly in Japan (Jing et al., 2018) and Europe as well as those in larger cities, have run out of permanent space. In Tokyo, for example, traditional burial plots are extremely scarce and expensive (Guo et al., 2016), and in London, a space crisis led Harriet Harman to propose reopening old graves for "double-decker" burials (Chen et al., 2016). Some cities in Germany do not have plots for sale; they have plots only for lease. When the lease expires, the remains are disinterred and a specialist bundles the bones, inscribes the forehead of the skull with the information that was on the head-stone, and places the remains in a special crypt. 


\section{CONCLUSION}

Soil, as a natural resource used by man also, has the function of protecting man to ensure that human life continues to exist on the earth surface. Soil as the provider of food and clothing palliatives, and home for the dead bodies associated with COVID-19 has saved the world from the COVID19 pandemic. It is important the world appreciates the role of soils in saving human race and ensures also of its protection because when the soil is protected life on earth is saved and sustained.

\section{REFERENCES}

Allton K.A. (2013). Soil Science Education (Commentaries). International Year of Soil Science, Madrid. http://www.soils.org.uk/media/uploads/press releases/pressR_ENSA2013.pdf

Asadu C.L.A. (2012). The soil we do not know. 81 $1^{\text {st }}$ Inaugural Lecture at the University of Nigeria, Nsukka

Bürgmann H. (2011). Methane oxidation (aerobic). In: Reitner J. and Thiel V. (eds.), Encyclopedia of Geobiology. Encyclopedia of Earth Sciences Series, Springer, Dordrecht. DOI: 10.1007/978-1-40209212-1 139

Chen J., Shang Y., Wang W. et al. (2016). Hydrogen sulfide-mediated polyamines and sugar changes are involved in hydrogen sulfide-induced drought tolerance in Spinacia oleracea seedlings. Front. Plant Sci., 7, 1173. DOI: 10.3389/fpls.2016.01173

Christou A., Manganaris G.A., Papadopoulos I. and Fotopoulos V. (2013). Hydrogen sulfide induces systemic tolerance to salinity and non-ionic osmotic stress in strawberry plants through modification of reactive species biosynthesis and transcriptional regulation of multiple defence pathways. J. Exp. Bot., 64, 1953-1966. DOI: 10.1093/jxb/ert055

Clark M., Worrell M. and Pless J. (1997). Postmortem changes in soft tissues. In: Haglund W.D. and Sorg M.H. (eds.), Forensic Taphonomy: The Postmortem Fate of Human Remains (pp. 151-164). CRC Press

Dent B., Forbes S. and Stuart B. (2004). Review of human decomposition processes in soil. Environ. Geol., 45 (4), 576-585. DOI: 10.1007/s00254-0030913-zS2CID129020735

FAO (1976). A framework for land evaluation. FAO Soil Bulletin No. 32, Food and Agriculture Organization (FAO) of the United Nations, Rome

Forbes S. (2008). Decomposition chemistry in a burial environment. In: Tibbett M. and Carter D. (eds.), Soil Analysis in Forensic Taphonomy (pp. 203-223). CRC Press, ISBN 978-1-4200-6991-4

Guo H., Xiao T., Zhou H., Xie Y. and Shen W. (2016). Hydrogen sulfide: A versatile regulator of environmental stress in plants. Acta Physiol. Plant., 38, 16. DOI: $10.1007 / \mathrm{s} 11738-015-2038$

Hillel D.J. (1991). Out of the earth: Civilization and the life of the soil. The Free Press: Macmillan, NY

Janaway R., Percival S. and Wilson A. (2009). Decomposition of human remains. In: Percival S.L. (ed.), Microbiology and Aging (pp. 13-334). Springer Science + Business
Jing W., Li N., Li X., Li D. and Wang L. (2018). Exchange fluxes of VOSCs between rice paddy fields and the atmosphere in the oasis of arid area in Xinjiang, China. J. Atmos. Chem., 75, 17-32. DOI: 10.1007/s10874-017-9360-1

Kharma A., Grman M., Misak A. et al. (2019). Inorganic polysulfides and related reactive sulfur-selenium species from the perspective of chemistry. Molecules, 24 (7), 1359. DOI: 10.3390/molecules24071359

Kopriva S., Mugford S., Baraniecka P. et al. (2012). Control of sulfur partitioning between primary and secondary metabolism in Arabidopsis. Front. Plant Sci., 3, 163. DOI: 10.3389/fpls.2012.00163

Li Q. and Lancaster J. (2013). Chemical Foundations of Hydrogen Sulfide Biology. Nitric Oxide, 35, 21-34. DOI: 10.1016/j.niox.2013.07.001

Mietzsch M. and Agbandje-McKenna M. (2017). The good that viruses do. Ann. Rev. Virol., 4 (1), 3-5. DOI: 10.1146/annurev-vi-04-071217-100011

Pasnau R. (2002). Aquinas, St. Thomas. Summa Theologiae 1a, 75-89. Trans. Pasnau. Hackett Publishing, p. 17

Predmore B., Lefer D. and Gojon G. (2012). Hydrogen sulfide in biochemistry and medicine. Antioxid. Redox Signal, 17, 119-140. DOI: 10.1089/ars.2012.4612

Rennenberg H. and Herschbach C. (2014). Detailed view on sulphur metabolism at the cellular and whole-plant level illustrates challenges in metabolite flux analyses. J. Exp. Bot., 65, 5711-5724. DOI: 10.1093/jxb/eru315

SSSA (2021). Soil: Get the inside scoop. Soil Science Society of America Book Series, available online at www.societystore.org

SSSN (2013). Soil is life and it is alive. World Soil Day by the Soil Science Society of Nigeria, 05 Dec. 2013

Stimler K., Berry J. and Yakir D. (2012). Effects of carbonyl sulfide and carbonic anhydrase on stomatal conductance. Plant Physiol., 158, 524-530. DOI: 10.1104/pp.111.185926

Stromberg J. (2015). The science of human decay (inside the world's largest body farm). Online at https://www.vox.com/2014/10/28/7078151/

Sublette S., Kathleen K., Flagg G. and Martin D. (1992). Final Celebrations: A Guide for Personal and Family Funeral Planning. Pathfinder Publishing, p. 52

Wikipedia. (2021). Chemical process of decomposition. Available online https://en.wikipedia.org/wiki/ chemical_process_of_decomposition

WHO (2020). Remarks by WHO Director General at a mission-briefing-on-COVID-19 on 12-March-2020 Accessed 16 May 2020 from: https://www.who.int/ $\mathrm{dg} /$ speeches/detail/who-director-general-s-opening

WHO (2021). Coronavirus (COVID-19) overview dashboard. World Health Organization, Online at https://covid19. who.int

Zhu N., Zhang D., Wang W. et al. (2020). Novel coronavirus investigating and research team: A novel coronavirus from patients with pneumonia in China. 2019. N. Engl. J. Med., 382 (8), 727-733. DOI: 10.1056/NEJMoa2001017

Zundhld S.S. (2021). Non-metal oxides. Encyclopedia Britanica. Online at https://www.britannica.com/ science/oxide 